\title{
Pergeseran Gaya Estetis Mebel di Keraton Ngayogyakarta Hadiningrat
}

\author{
Indah Septi*\& Agus Sachari** \\ *Jurusan Kria, Fakultas Senirupa ISI-Yogyakarta \\ **KK Ilmu Desain dan Budaya Visual, Fakultas Senirupa dan Desain ITB
}

\begin{abstract}
Abstrak. The Kraton Ngayogyakarta Hadiningrat has been the center for the development of ideas, traditions, and cultural artifacts, giving it a unique status among Indonesia diverse cultures. Understanding the richness of Yogya's inherited artifacts, this research tried to investigate the existing styles of furniture in the Keraton Ngayogyakarta Hadiningrat during 1755 to 1988. The span period was chosen because during that time the Keraton endured several cultural transformations, from the period where Hindu-Buddha was very much influential to the era of colonialism. Sources for this research were gained through direct observation, interview and documentation, amplifying descriptive qualitative method using historical approach for analysis.

The study indicates that there exist visual data, left by Sri Sultan Hamengku Buwono VIth to IXth, in form of symbolic mean that could be seen on the furniture (ornaments) in the Keraton Ngayogyakarta Hadiningrat. It shows that the most frequent used ornaments are geometric shape, flora-fauna, and imaginary creatures. The ornaments are usually placed at the top, center and lower parts of the furniture. Aside to fulfill aesthetical decoration, those ornaments, which also have symbolic mean, are used as a medium to express the social norms of the Kraton Ngayogyakarta Hadiningrat.
\end{abstract}

Keywords: style; furniture; kraton Ngayogyakarta.

\section{Sejarah Bangunan Keraton}

Wilayah Yogyakarta merupakan daerah dan penting di Indonesia, karena di wilayah ini berkembang kebudayaan yang khas dan unik. Keunikan budaya tersebut salah satu di sebabkan oleh pengaruh budaya keraton. Selain itu, kesenian dan kerajinan pun banyak tumbuh di sekitar keraton, hal tersebut kemudian amat mendukung laju roda ekonomi rakyat, di antaranya kerajinan perak, batik, bambu, topeng, keramik, kulit, wayang, gamelan dan lain sebagainya, termasuk di dalamnya padepokan tari dan teater merupakan potensi daerah yang handal. Bahkan Yogyakarta adalah salah satu pusat pendidikan dan wisata karena terdapat beberapa objek suaka purbakala di sekitarnya.

Received October $12^{\text {th }}$ 2007, Revised February $18^{\text {th }}$ 2007, Accepted for publication March $5^{\text {th }} 2007$. 
Bangunan Keraton Yogyakarta adalah merupakan bentuk kebudayaan lainnya yang membentuk keunikan daerah ini. Proses pembangunan keraton dilaksanakan di zaman Sri Sultan Hamengku Buwono I pada tahun 1756, sebagai akibat politik kolonial yang menjembatani antara Sultan dengan "pemerintah luar" atau "parentah jaba". Sebagai ibu kota kerajaan, keraton merupakan tempat kedudukan "parentah jaba" dan merupakan tempat kediaman para pangeran dan para pejabat tinggi lainnya. Sebelum Mataram pecah menjadi Surakarta dan Yogyakarta pada tahun 1755, sebagian besar terletak di dalam nagaragung Mataram ditambah sebagian daerah mancakerajaan yang menjadi daerah taklukan. Ketika Yogyakarta membentuk lingkaran-lingkaran kerajaan sendiri pada tahun 1755, dimulailah dengan membangun keraton, yang tetap bertahan hingga kini, kemudian berturut-turut menentukan batas-batas negara, negaragung, dan mancanegara. (Selo Sumardjan : $1991:$ 30).

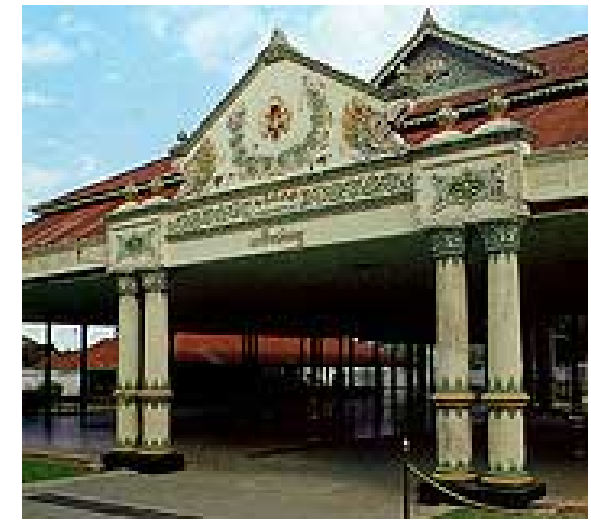

(a)

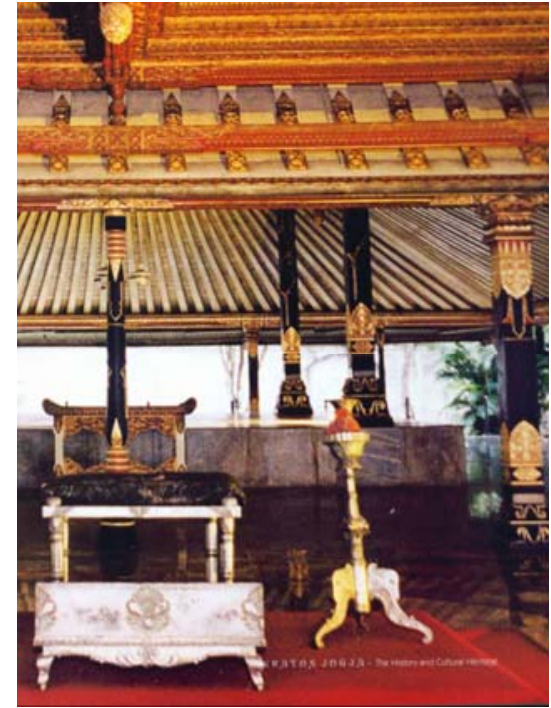

(b)

Gambar 1 (a) Bagian depan bangunan keraton Yogyakarta; (b) Susunan mebel di salah satu pendopo keraton Yogyakarta.

Seiring dengan perjalanan sejarah keraton di tanah Jawa, di samping bangunan istana berkembang pula pelbagai produk yang mengisi interior keraton itu. Salah satu yang utama adalah barang perabotan dan mebel. Artifak tersebut diciptakan beragam jenis, sesuai dengan kebutuhan istana. Mebel di dalam keraton tidak hanya mengutamakan fungsi kebutuhan akan fungsi semata, melainkan terdapat nilai-nilai lain yang mendasarinya seperti nilai simbolis dan nilai estetis. 


\section{Awal Perkembangan Gaya Estetis Mebel di Jawa}

Keberadaan kebudayaan Jawa telah berlangsung selama berabad-abad, dan telah banyak menghasilkan produk budaya yang mengandung nilai-nilai sejarah tinggi. Sedangkan budaya Jawa sendiri berdasarkan letak geografisnya dapat dibedakan ke dalam Jawa Pedalaman dan Jawa Pesisir, keduanya memiliki sistem nilai yang berbeda.
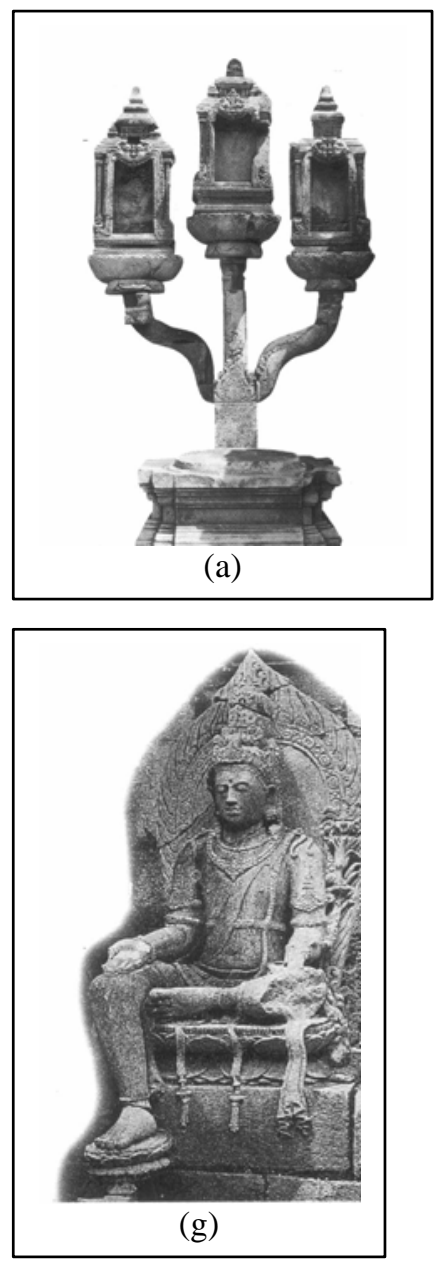

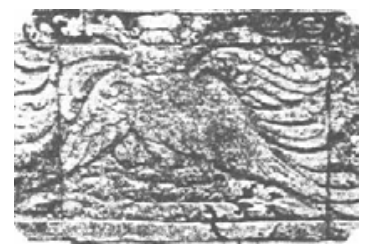

(b)

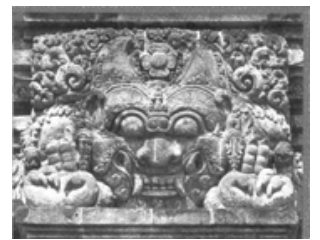

(c)

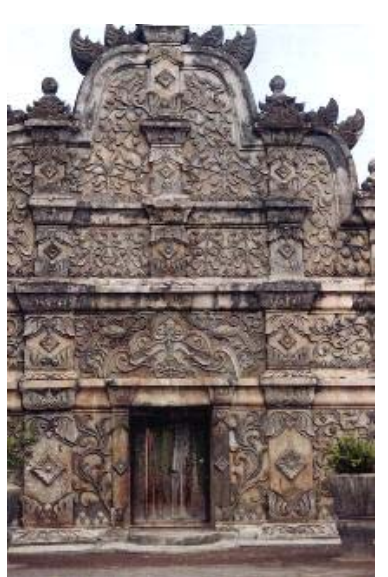

(f)

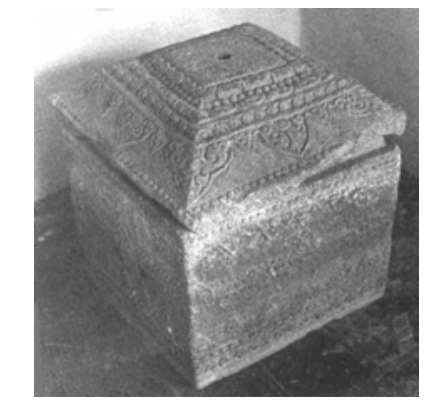

(d)

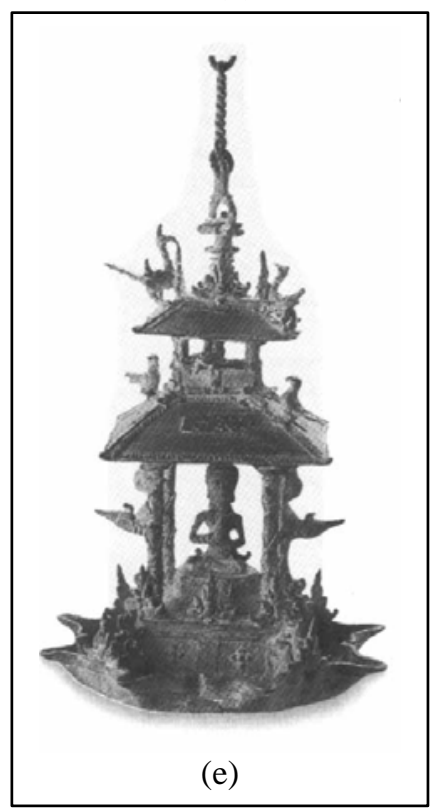

Gambar 2 (a) Lampu minyak di zaman Hindu terbuat dari batu; (b) Ragam hias burung garuda pada relief candi; (c) Ragam hias Kala pada pintu gerbang candi zaman Hindu; (d) Tempat pakaian (lemari) terbuat dari batu; (e) Lampu minyak gantung zaman Hindu; (f) Relief ragam hias Hindu pada bangunan Tamansari; (g) Kursi singgasana raja Jawa di zaman Hindu (Sumber: Indonesian Heritage). 
Budaya Jawa Pesisir merupakan keseluruhan pengetahuan atau kebudayaan yang dimiliki dan terjiwai oleh masyarakat Pesisiran. Salah satunya adalah budaya dagang merupakan salah satu bentuk budaya yang berkembang pesat di kawasan Pesisir Jawa, terutama daerah yang mudah untuk mengadakan kontak dengan masyarakat luar Jawa. Dengan adanya hubungan tersebut, kemudian memiliki dampak yang positif terhadap tumbuhnya masyarakat niaga. Berbeda dengan masyarakat Jawa Pedalaman yang lebih lamban pertumbuhan perdagangannya, karena sulit untuk melakukan kontak dengan budaya luar.

Mebel sebenarnya merupakan artifak baru bagi masyarakat Jawa setelah meredupnya kebudayaan Hindu di tanah Jawa dan mulai memasuki era pemerintahan kolonial. Semasa kebudayaan Hindu, masyarakat Jawa telah memiliki sejenis 'mebel', baik yang terbuat dari batu, kayu, bambu maupun logam. Beberapa jenis singgasana raja, sejenis lemari batu, lampu batu dan hiasan ruang, masih dapat dilihat pada sejumlah peninggalan yang ditinggalkannya. Meskipun terjadi perubahan dalam gaya hidup masyarakat Jawa pengaruh ragam hias Hindu masih bertahan dan mengalami proses akulturasi dengan artifak baru tersebut.

Kemampuan orang Jawa membuat mebel sebenarnya telah ada sejak masa peralihan dari kebudayaan Hindu-Budha ke kebudayaan Islam, kemudian berkembang semasa pemerintahan kolonial, dan puncaknya ditandai dengan kemampuan mengekspor beberapa jenis kursi ke pelbagai negara, antara lain: Burgomaster chair" atau dikenal dengan kursi "Bakul" secara besar-besaran ke benua Eropa oleh Burgomaster (berkebangsaan Belanda) pada tahun 1650. Kemudian pada masa VOC juga terdapat upaya mengimpor mebel dari Eropa, khsususnya Perancis yang kemudian di Jawa disebut gaya "Perancisan" pada tahun 1700. Hal tersebut masih berlanjut pada masa pemerintahan Thomas Stanford Raffles, seorang Gubernur Jenderal yang mewakili pemerintahan Inggris di Jawa (1811-1816), dengan mendatangkan kursi Eropa dengan gaya Rococo di Perancis abad ke-15, kemudian kursi tersebut dikenal oleh masyarakat pertukangan sebagai kursi Rafflesan.

Keraton merupakan refleksi dari kebudayaan Jawa yang berakulturasi dengan kebudayaan asing kemudian berkembang di masyarakat, bahkan untuk hal tertentu merupakan refleksi kualitas terbaik dari kebudayaan yang tumbuh di sekitarnya. Hal itu terlihat pada desain bangunan keratin, pakaian para raja hingga mebel yang menjadi bagian dari kehidupan keraton itu.

\section{$3 \quad$ Inspirasi Ragam Hias Mebel Keraton Yogyakarta}

Sejumlah ragam hias dan gaya mebel yang terdapat di keraton Surakarta amatlah beragam. Penempatannya pun kerap acak dan tidak sejalan dengan 
ragam hias ruang dalam atau elemen estetik lingkungannya. Hal tersebut dikarenakan penempatan mebel yang lebih dinamis disesuaikan dengan 'peristiwa' atau upacara yang biasa dijalankan di dalam keraton.

Ragam Hias yang diterapkan pada mebel yang ada di keraton Ngayogyakarta Hadiningrat jenisnya bermacam-macam. Antara lain Ragam hias tumbuhtumbuhan yang diwujudkan dalam bentuk pola hias sulur-suluran yang juga banyak berkembang pada bangunan zaman kerajaan di Indonesia. Oleh karenanya dikenal sebutan pola yang menggunakan nama-nama kerajaan itu, seperti ragam hias Kerajaan Pejajaran, Majapahit, Bali, Mataram, Jepara, Madura, Pekalongan, Cirebon, Surakarta dan Keraton Ngayogyakarta Hadiningrat.

Ragam hias yang ada di keraton Yogyakarta banyak di pengaruhi oleh ragam hias bercorak Hindu, Budha, Cina, keIslaman dan bahkan Eropa. Pengaruh ragam hias tersebut banyak berbentuk bunga mawar, naga, garuda, yang umumnya terdapat pada candi - candi atau pada bangunan lainnya. Bentuk ragam hias yang ada pada bangunan keraton di antaranya sebagai berikut:

\subsection{Ragam Hias Ular Naga}

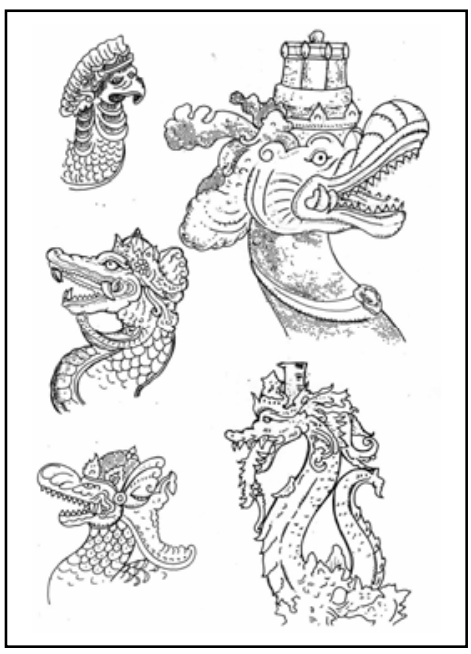

(a)

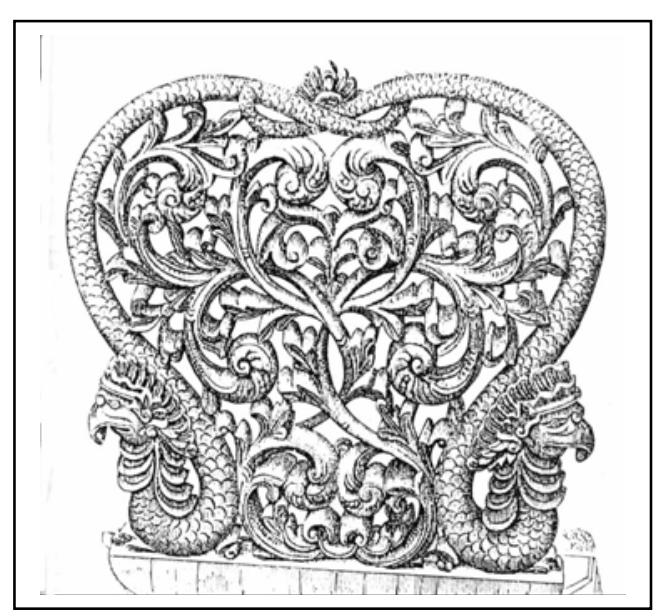

(b)

Gambar 3 (a) Pelbagai macam ragam hias naga; (b) Kombinasi ragam hias naga dan fauna (Sumber: Pepin, 1998). 

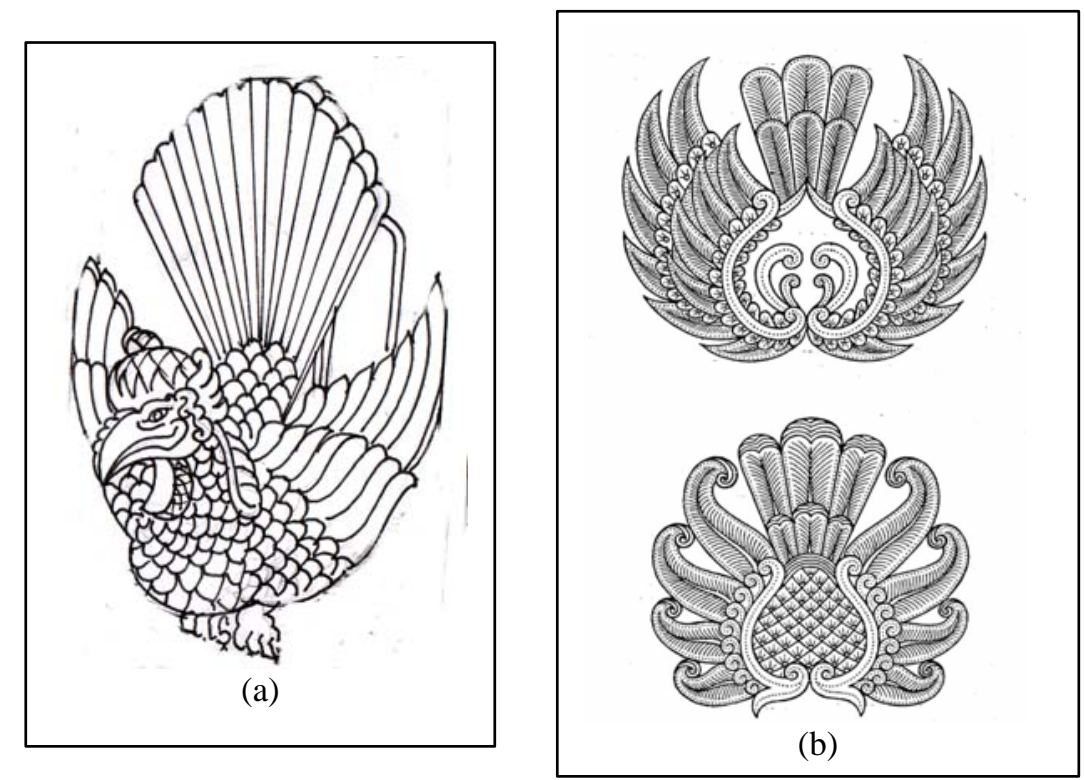

Gambar 4 (a) Ragam hias burung Garuda dengan kepala merunduk; (b) Ragam hias sayap burung Garuda (Sumber: Sugeng Toekio, 1992).

Selain naga, inspirasi ragam hias diperoleh dari burung garuda yang telah menjadi bagian dari ragam kebudayaan Hindu di tanah Jawa selama berabadabad. Ragam hias garuda, umumnya telah mengalami stilasi, yang dicuplik hanya bagian sayap, ekor atau kepalanya saja.

\subsection{Ragam Hias Tumbuhan dan Bunga}

Ragam hias bunga teratai dibuat atau digambarkan sedemikian rupa dengan artistik, Beberapa sumber menyebutkan bahwa bunga teratai adalah merupakan "bunga yang di surga” atau nirwana karena keraton diibaratkan sebagai surga. Titik tengah merupakan "pancer" yang menyatakan bahwa segala sesuatu pada diri manusia itu ada lubang "kiblat papat lima pancer", bahwa sesuatu yang terarah menuju ke yang Maha Kuasa harus menjadi satu "pancer” menyatunya segala sesuatu pada diri kita untuk menuju pada Tuhan.
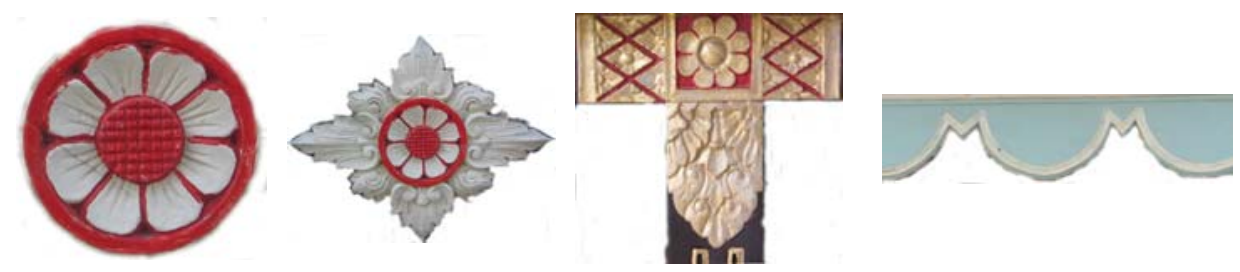

Gambar 5 Motif bunga teratai dan motif geometris. 
Di Keraton Ngayogyakarta Hadiningrat umumnya ragam hias terdapat pada umpak yang bermotif ragam hias padma sebagai lambang kesesuaian yang bermakna identik dengan arti kokoh dan kuat, atau di ukir dengan huruf Arab dengan kata saluh atau waloh yang tidak berbeda jauh dengan bunyi kata Allah.

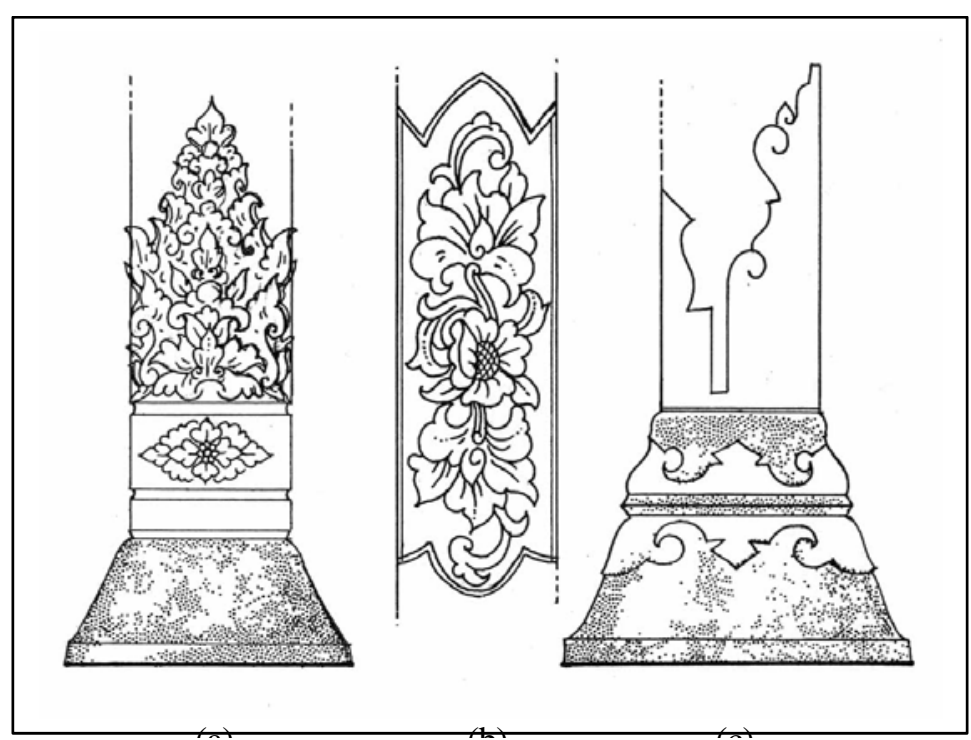

Gambar 6 (a) Ragam hias praba; (b) Ragam hias Lunglungan; (c) Ragam hias Mirong (merupakan perkawinan antara tulisan kaligrafi Arabik dan ragam hias Jawa (Sumber: Sugeng Toekio, 1992).

\subsection{Ragam Hias Geometris (Wajikan)}

Kata wajikan berasal dari kata "wajik", ialah nama sejenis makanan yang dibuat dari beras ketan, dan memakai gula kelapa. Dinamakan wajikan sebab bentuknya seperti irisan wajik (belah ketupat sama sisi), istilah lainnya adalah "sengkulunan", yakni motif batik yang bentuknya juga belah ketupat. Hiasan ini ada yang memakai garis tepi dan ada yang tidak, bagian tengah diisi dengan ornamen daun-daunan yang tersusun memusat.
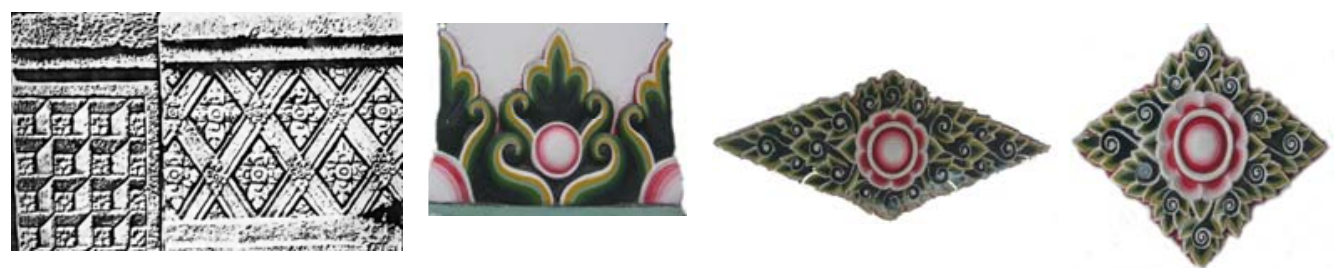

Gambar 7 Motif Wajikan (Sengkulunan). 


\subsection{Ragam hias Mataram dan Majapahit}

Corak hias mataram bentuknya diambil dari bentuk jenis ukiran wayang kulit yang berbentuk krawingan sebagai bentuk dasarnya. Corak hias Mataram berbentuk tumbuh-tumbuhan yang berbentuk melingkar ke kanan dan ke kiri dengan isian daun-daun trubusan, bunga maupun buah.

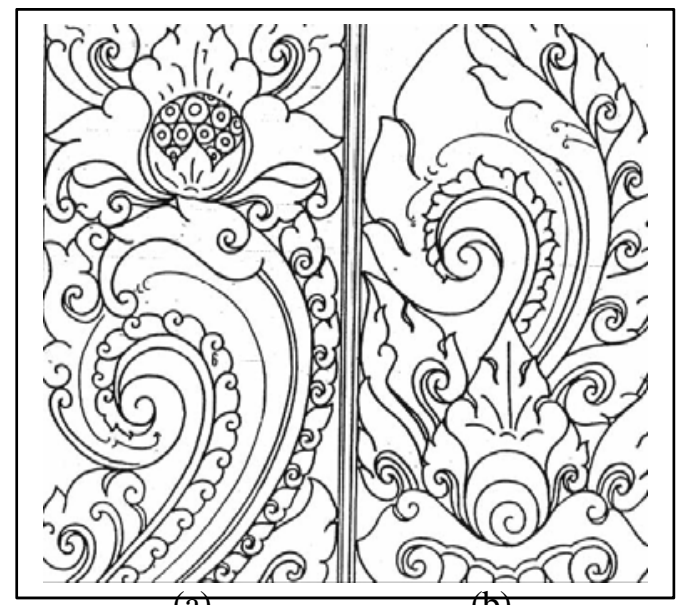

Gambar 8 (a) Ragam hias Mataram; (b) Ragam hias Majapahitan (Sumber: Sachari,1990).

\subsection{Ragam hias Eropa}

Selain pengaruh Cina yang telah terlebih dahulu mewarnai ragam hias mebel di tanah Jawa, ragam hias yang berasal dari benua Eropa memasuki wilayah Nusantara awalnya telah ada sejak kunjungan perdagangan bangsa-bangsa Eropa ke tanah Jawa. Terjadinya pemesanan barang mebel di sejumlah daerah di Jawa Tengah oleh pedagang Belanda telah menumbuhkan pertukaran kebudayaan, baik kebudayaan Eropa ke tanah Jawa, maupun sebaliknya. Namun pengaruh itu semakin menguat sejak masa kolonial, baik semasa kolonialisasi Belanda dan juga Inggris meskipun singkat ${ }^{[11]}$.

Banyak pengrajin mebel di Jawa mendapat inspirasi dari sejumlah contoh mebel dan gambar yang di bawa oleh bangsa Eropa ke tanah Jawa. Sejumlah mebel ditiru dan sebagian dikawinkan dengan ragam hias daerah setempat, sehingga berkembanglah ragam hias campuran antara ragam Eropa dan ragam Jawa. 

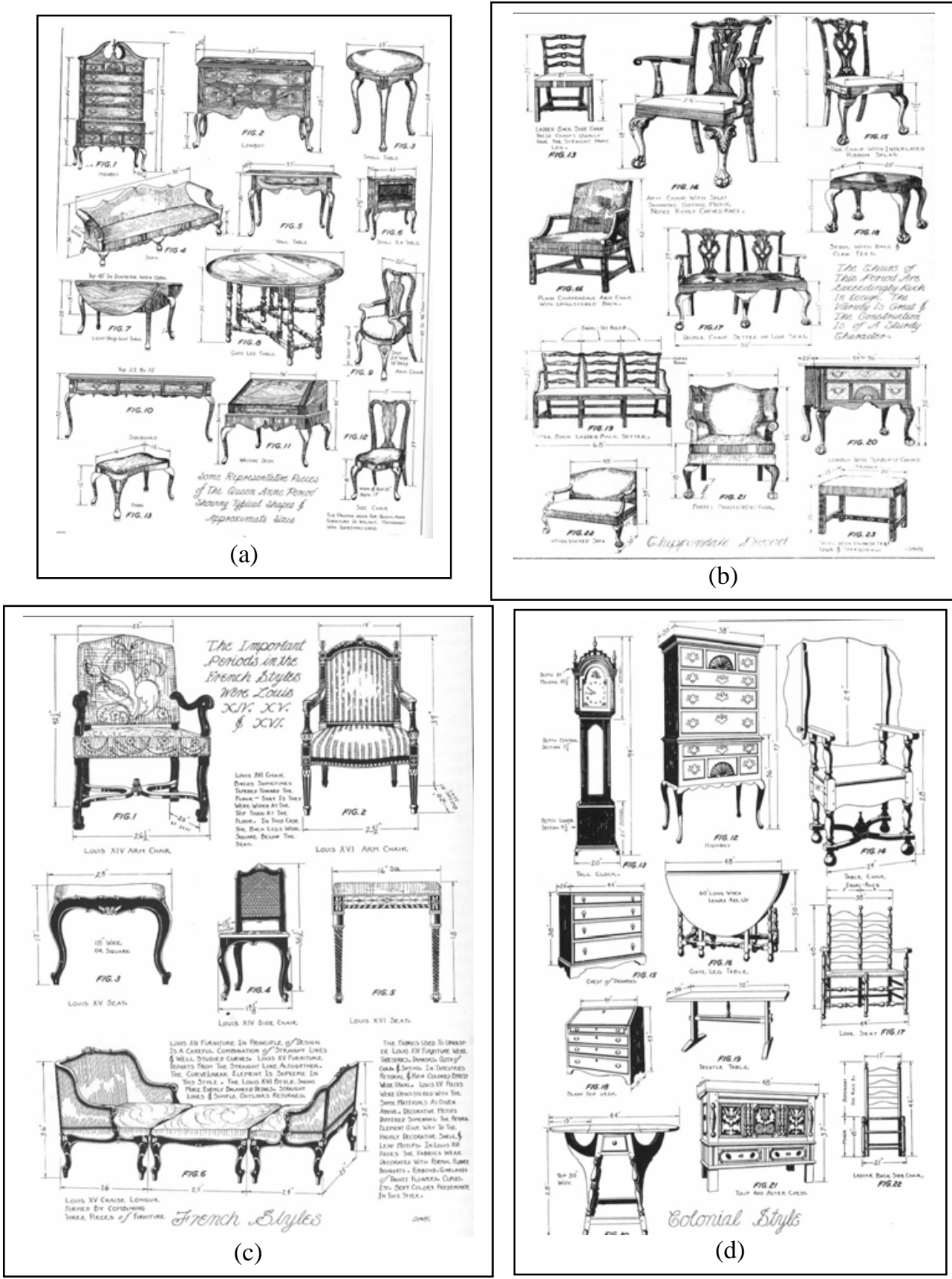

Gambar 9 Gaya mebel Eropa abad pertengahan yang menjadi inspirasi mebel di keraton Surakarta dan Yogyakarta (a) Gaya Queen Anne; (b) Gaya Chipendalle; (c) Gaya Perancis; (d) Gaya Kolonial (Sumber: Gottshall, 1989). 


\section{$4 \quad$ Keberadaan Mebel di Keraton Ngayogyakarta Hadiningrat}

Sejak masa pemerintahan Hamengku Buwono ke-I sampai dengan Hamengku Buwono ke-IX keberadaan mebel di keraton mengalami pelbagai nuansa perubahan. Hal tersebut karena mulai dari zaman Hamengku Buwono I sampai dengan Hamengku Buwono IV pengadaan mebel di keraton amat terbatas, disebabkan pada saat itu keraton sedang berperang dengan pemerintah kolonial Belanda, sehingga raja tidak sempat memikirkan pembuatan mebel ataupun membenahi keraton. Begitu pula pada masa Hamengku Buwono V dan VI tidak terdapat peninggalan mebel yang penting, diperkirakan pada waktu itu kerajaan sedang kesulitan keuangan.

Baru pada masa HB ke-VI mulai membuka diri untuk menerima tamu-tamu asing, terutama pejabat Belanda sehingga membutuhkan mebel yang lebih baik untuk menghormati tamu. Pada masa Hamengku Buwono ke-VII, VIII dan IX sampai sekarang, terdapat sejumlah mebel, baik yang dibuat oleh pengrajin kayu di sekitar keraton, maupun hadiah dari tamu asing untuk keraton.

Sejak Hamengku Buwono VII, telah menjadi kelaziman bahwa pembuatan mebel di keraton dikerjakan oleh perajin yang mengabdikan diri pada pekerjaannya untuk kepentingan kerajaan, dan pada setiap pembuatan mebel ataupun bangunan tidak boleh disebutkan nama pembuatnya dikarenakan dihadapan raja seseorang yang berprestasi tidak lazim untuk menonjolkan diri. Demikian pula kepemilikan mebel saat itu masih terbatas pada keluarga bangsawan atau orang-orang yang bekerja di keraton saja.

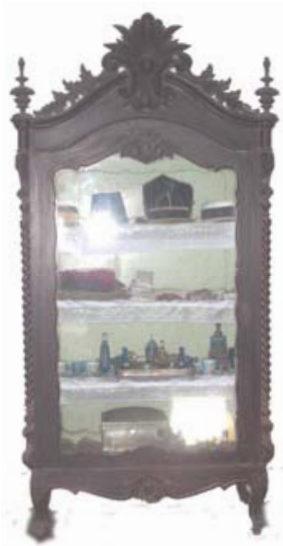

(a)

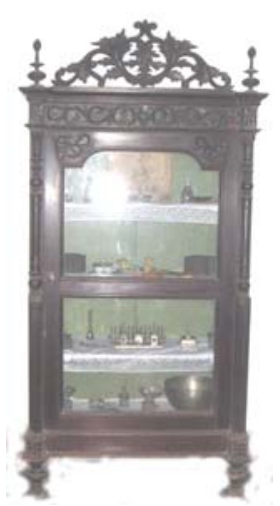

(b)

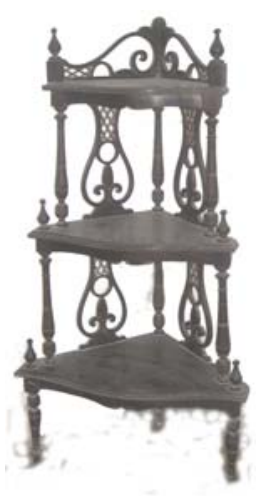

(c)

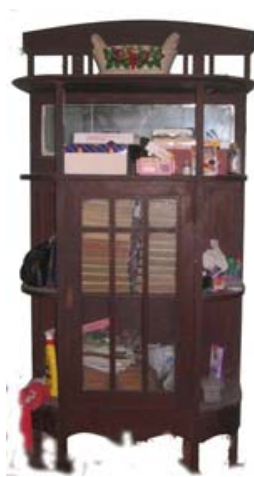

(d)

Gambar 10 Pelbagai almari milik HB Ke-VII yang kemudian dihadiahkan kepada cucunya. 
Dari fenomena tersebut dapat di pahami bahwa keberadaan mebel di keraton berkembang sesuai dengan kebutuhan keluarga raja yang tinggal di keraton selama beberapa kali pergantian pemerintahan. Bukti-bukti peninggalan mebel yang masih terdapat di keraton menunjukkan bahwa selera raja yang tinggal di keraton amat beragam, di antaranya mereka dapat menerima gaya estetik produk-produk mebel kiriman dari Eropa maupun produk lokal, baik berupa kursi, meja, lemari, maupun jenis-jenis mebel lainnya.

Dalam perjalanan sejarah, sebagian mebel yang ada di keraton sebagian diwariskan pada anak, cucu, dan keluarga keraton, sebagian lagi dibuat duplikatnya untuk diberikan kepada keluarga keraton. Dari sejumlah peninggalan mebel tersebut sebagian kondisinya masih baik dan dilestarikan. Sebagian peninggalan mebel tersebut berada di rumah Pakuningratan dan di rumah Gusti Yudho.

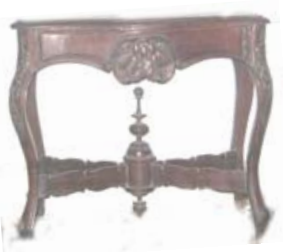

(a)

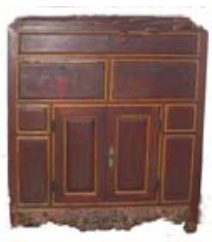

(b)

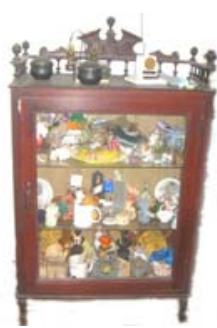

(c)

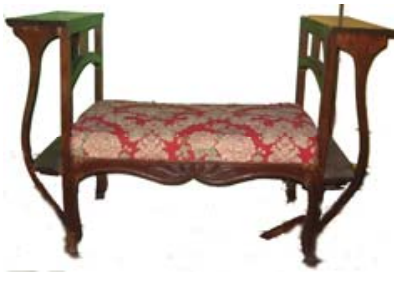

(d)

Gambar 11 Berbagai mebel milik HB Ke-VII dihadiahkan untuk cucunya.

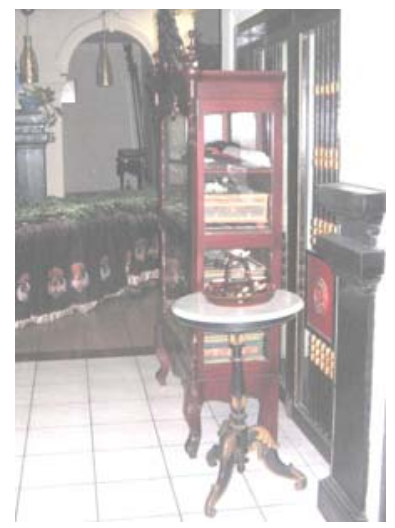

(a)

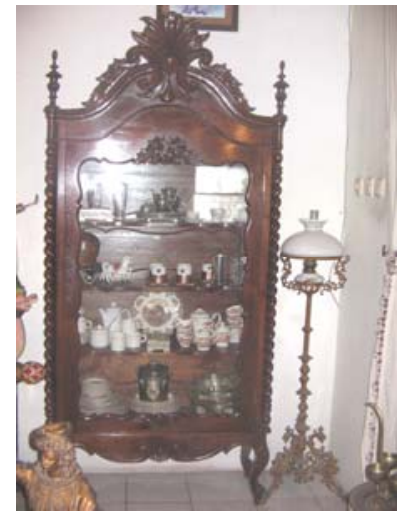

(b)

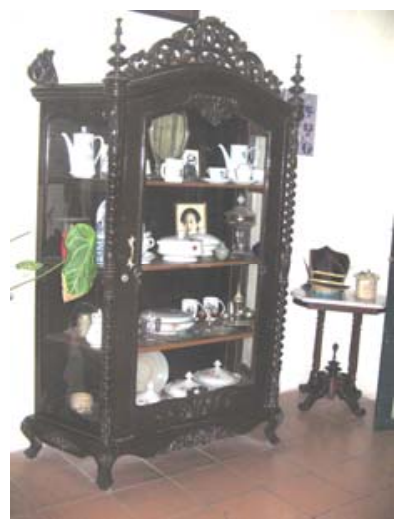

(c)

Gambar 12 Berbagai mebel yang dihadiahkan oleh HB Ke-VII dan VIII kepada Gusti Yudho. 
Sebagian ragam hias yang diterapkan pada mebel buatan pengrajin istana sering dikaitkan dengan nilai-nilai filosofis yang dianut dan berlaku di lingkungan keraton. Demikian pula bentuk visual yang sangat indah di dalamnya diniali mengandung nilai-nilai budaya yang adiluhung. Mebel milik raja sering di identikkan dengan sosok raja itu sendiri. Hal itu berkaitan dengan adanya pandangan bahwa raja merupakan penjelmaan dewa yang telah meresap dalam kehidupan masyarakat Jawa. ${ }^{[5]}$

Jika kita menengok sejarah, kursi dari bahan kayu mulai populer sejak pemerintahan kolonial, walaupun tercatat kursi-kursi dari dataran Cina sudah mulai digunakan di Jawa. Sebagaimana diketahui, bahwa sejenis sarana duduk di Jawa telah ada sejak jaman Hindu, masyarakat Jawa mulai hidup dalam sebuah kerajaan. Raja ditetapkan sebagai "Panatapraja", yang berarti penguasa atau pengatur negara dan "Panatagama", yaitu penguasa serta pemimpin agama. Raja merupakan manusia dengan kedudukan tertinggi dalam susunan masyarakat dan dianggap sebagai titisan dewa. Sebagai bentuk penghormatan terhadap kedudukannya disediakan tempat duduk seperti yang digunakan para dewa. Tempat duduk yang digunakan raja dinamakan "Singghasana", sedangkan sikap duduk ini dinamakan "Lalitasana", yang berarti sikap duduk dalam ketenangan seorang raja. ${ }^{[11]}$

Sikap duduk di atas singgasana tersebut sebenamya merupakan pemunculan bentuk perlambangan megalitik, seperti yang dikatakan oleh H.R. Van Heekeren dalam buku "The Bronze Iron Age of. Indonesia" yang disebut "Spirit Seat", Di maksudkan sebagai pemujaan pada roh nenek moyang, seperti sarana duduk yang ditemukan di Desa Cerium, Semarang. ${ }^{[14]}$

Berkaitan dengan pandangan tersebut, keberadan kursi raja selain sebagai tempat duduk mempunyai arti lain yaitu sebagai perlambangan tahta, kekuasaan atau wilayah negara. Dalam masyarakat Jawa, istilah "nglenggahi" atau duduk di atas singhasana berarti duduk di atas tahta kerajaan. Atas dasar inilah kecuali raja, duduk di atas singhasana atau tempat duduk yang menyerupai singhasana mendapat wulat-kuwalat atau "kutukan", sehingga duduk seperti halnya seorang raja bagi masyarakat Jawa lama dianggap sebagai sesuatu yang tabu.

\section{Mebel dalam Kehidupan Keraton Ngayogyakarta Hadiningrat}

Mebel dalam kehidupan keraton Ngayogyakarta Hadiningrat merupakan salah satu hal yang berperanan sangat penting dalam mengarahkan dan menentukan pilihan gaya visual bagi para perajin mebel di sekitar keraton dalam membuat mebel yang unik dan menarik. Bahan yang digunakan untuk membuat mebel keraton hampir semuanya menggunakan bahan kayu sawo kecik. Hal itu bagi 
masyarakat Jawa mengandung arti memiliki arti kesejatian atau arti yang baik halus dan kuat, dan bahan "sawo kecik" yang maknanya bahwa "jatine seorang pemimpin kudu sarwo becik“.

Dalam sistem pemerintahan monarki, keraton memiliki peran yang sangat penting dan strategis, karena semua hal kehidupan kemasyarakatan diatur dan ditentukan oleh raja. Pada masa lampau umumnya perajin mengabdikan diri pada pekerjaannya untuk kepentingan kerajaan. Pada zaman Hindu diperoleh gambaran, bahwa di dalam masyarakat Jawa terdapat sistim birokrasi yang mengatur berbagai usaha dan bidang keahlian yang menunjukkan diferensiasi dan spesialisasi kerja. Semangat perajin dalam mengabdikan diri pada kerajaan, biasanya dilandasi dengan semangat sesuai dengan ajaran agama yang dianut. Oleh karena itu dapat dipahami bahwa perajin, masyarakat, pemimpin agama, dan aparatur pemerintah dapat bekerja sama dengan baik. Sikap kekeluargaan dan kegotong royongan terus mengakar, tumbuh dan berkembang semakin baik di dalam maupun di luar pintu gerbang kerajaan, hingga terbentuklah komunitas yang semakin mantap dan berpengaruh terhadap munculnya kelompok industri mebel ukir.

Masyarakat yang tinggal di luar istana pun umumnya bermukim di perkampungan atau sentra-sentra industri yang letaknya tidak jauh dari keraton. Oleh karena itu dipandang sebagai pengabdian kepada raja yang dipuja, maka para perajin dalam menyelesaikan pekerjaannya tidak tergantung pada yang lainnya selain mengabdi pada raja. Pada masa pemerintahan kerajaan, para perajin sudah mengenal pembagian tugas sesuai dengan keahliannya, termasuk pengrajin mebel.

Pada zaman itu, kepemilikan dan gaya mebel yang terdapat di keraton tidak dapat ditiru oleh penduduk secara luas, kepemilikan mebel saat itu masih terbatas pada keluarga bangsawan atau orang-orang yang bekerja di dalam keraton dan di luar keraton saja. Namun setelah aktivitas para perajin di dalam keraton semakin bertambah jumlahnya, tumbuh semacam industri kecil yang memproduksi mebel. Pelahan-lahan industri mebel tumbuh pula di luar keraton dan mulai menyentuh berbagai kalangan masyarakat umum

\section{Gaya Estetis Mebel Keraton Ngayogyakarta Hadiningrat}

Gaya estetis mebel yang berada di keraton Ngayogyakarta Hadiningrat dalam beberapa perioda kekuasaan raja, dipengaruhi oleh pelbagai ragam kebudayaan yang tumbuh sebelumnya, maupun gaya yang dibawa oleh pemerintah kolonial ke pulau Jawa. Kedekatan raja Jawa dengan pemerintah kolonial, secara bertahap telah membangun proses akulturasi, tidak hanya pada gaya estetis mebel, namun juga busana raja, bangunan, persenjataan, kereta raja hingga 
pelbagai macam barang sehari-hari. Secara konprehensif, proses akulturasi tersebut dipengaruhi oleh persilangan antara budaya Jawa asli dengan kebudayaan dari luar.

\subsection{Pengaruh Hindu}

Pada relief candi Mendut dijumpai penggambaran bentuk rumah yang selanjutnya di anggap sebagai bentuk awal rumah Jawa. Bentuk tersebut dikenal dan disebut rumah panggung, yaitu rumah yang dibangun di atas tiang penopang. Susunan rumah secara keseluruhan dibagi menjadi tiga bagian, yaitu: atap, ruang rumah, dan kolong. Menurut Djumhur, bentuk susunan ini berdasarkan keperyaan Hindu, dan diartikan sebagai tingkatan hidup di alam semesta. Bagian atas (atap) sebagai alam roh, bagian ruang rumah adalah alam manusia, dan kolong adalah alam bawah. (Djumhur : 1972 : 16)

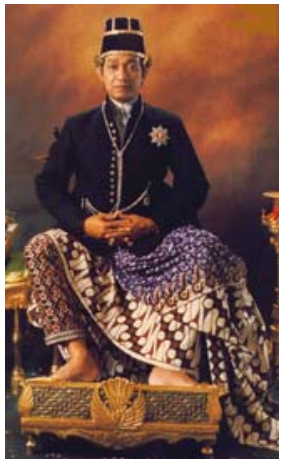

(a)

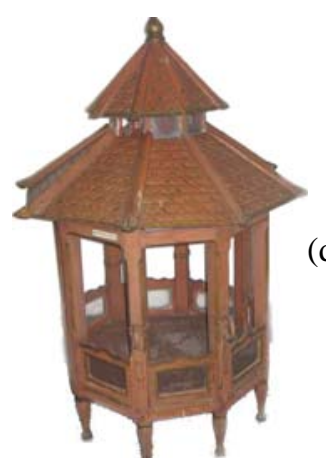

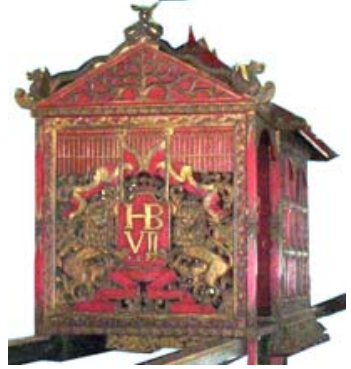

(b)

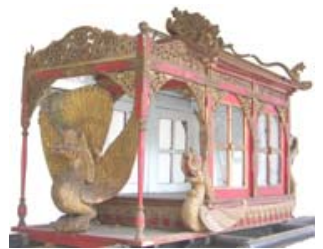

(c)

(d)
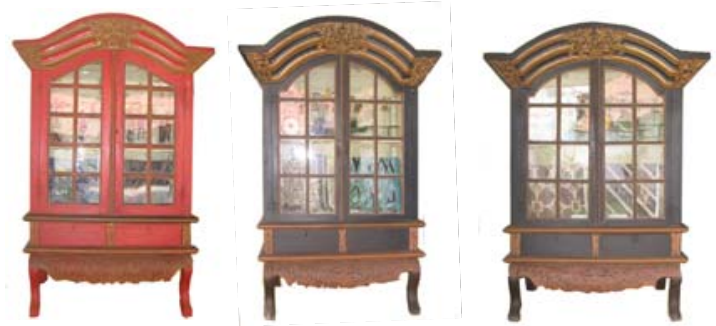

(e)

Gambar 13 (a) Damparan raja dengan ragam hias suluran dan garuda; (b) Usungan makanan dengan ragam hias suluran dan naga; (c) Tandu raja dengan ragam hias suluran, naga dan burung garuda; (d) 'Joli ' tempat peralatan untuk perkawinan agung (e) Sejumlah lemari paduan gaya Eropa dan Jawa yang dihadiahkan untuk Hamengku Buwono IX. 
Seperti pada candi, ruang rumah dibagi menjadi tiga bagian yaitu : pendapa, dalem dan sentong. Pendapa adalah ruang yang terbuka digunakan sebagai ruang tamu dan tampat berkumpul. Dalem merupakan inti dari rumah digunakan untuk keperluan upacara, dan dianggap sebagai tempat bagi kekuatan yang menjaga rumah atau keluarga, sentong adalah ruang untuk tidur.

Perlengkapan duduk dan kegiatan lainnya yang digunakan dalam kehidupan di dalam rumah kerap disebut "klasa" atau tikar (bahasa Indonesia). Kegunaannya tidak hanya terbatas sebagai penutup lantai atau alas ruang, melainkan digunakan sebagai tempat duduk, tempat tidur, tempat mengasuh anak serta tempat bekerja (memintal, menenun, membatik).

Ditinjau dari sikap duduk yang lazim dilakukan, mulai dari yang paling sopan adalah: sila, sila tumpang, timpuh, jengkeh, jegang, dan slonjor, klasa (tikar) merupakan perlengkapan yang paling sesuai dengan kebiasaan tersebut. Sebenarnya pada masa Hindu telah terdapat sarana duduk berupa bangku panjang, namun secara umum masyarakat kebanyakan cenderung melakukan duduk secara bersila.

\subsection{Pengaruh Budaya Eropa}

Sama halnya dengan keraton Surakarta Hadiningrat, budaya keraton yang menjunjung tinggi nilai-nilai simbolisme Jawa merupakan upaya untuk memperkuat pengakuan terhadap raja terhadap rakyatnya. Keadaan tersebut diperkuat oleh fungsi sebagai kekuasaan feodal yang memperkuat eksistensi budaya keraton. Mebel yang tumbuh di dalam keraton, awalnya belum dapat banyak ditiru oleh masyarakat di luar keraton, karena masih mentabukan dan menghormati raja sebagai perpanjangan dewa di muka bumi. Penyanjungan terhadap nilai-nilai tersebut, menyebabkan nilai estetis yang berkembang di keraton cenderung disakralkan oleh masyarakat kebanyakan .

Di dalam lingkungan keraton kegiatan dalam bidang kebudayaan atau kesenian merupakan salah satu yang diutamakan. Terbukti oleh adanya semacam sekolah yang khusus diperuntukkan bagi kalangan keraton. Peran sekolah ini disamping mempelajari masalah-masalah kebudayaan, peran lain adalah mengolah, membentuk dan mengembangkan bentuk kesenian yang selanjutnya dijadikan upaya pelestarian dan pewarisan kebesaran keraton. (Suprapto : 1973 :34).

Di wilayah Yogyakartapun, sejak bangsa Eropa(Portugis, Inggris, Belanda) datang ke tanah Jawa, kebudayaan Jawa mulai terpengaruh oleh kebudayaan Eropa tersebut. Gaya estetik yang sebelumnya banyak dipengaruhi kebudayaan Hindu, yang kemudian disebut kebudayaan Hindu-Jawa, mulai memudar dan 
sedikit demi sedikit berubah menjadi gaya Jawa-Eropa. (I. Djumhur : 1972 : 7) Para seniman keraton cenderung menerapkan ragam hias Eropa, kemudian dipadukan dengan gaya yang telah ada sebelumnya. Maksud penggabungan gaya ini adalah untuk memperkaya dan meninggikan kesenian/ kebudayaan Jawa.

Sikap tersebut berkelanjutan dengan menyilangkan berbagai gaya itu (dari kebudayaan Jawa dan kurun waktu yang berbeda) dengan ragam yang dibawa oleh bangsa Portugis, Belanda, Perancis, dan Inggris. (Raflles : 174) sehingga membentuk beberapa gaya baru yang disebut Portugisan, Kompeni, Perancisan, dan gaya Rafflesan. Kondisi tersebut samapula seperti yang terjadi di keraton Surakarta dan sekitarnya. Sedangkan penamaan gaya yang berkembang dari kebiasaan masyarakat Jawa sehari-hari menyebut ciri visual dan unsur paduan ragam Eropa pada mebel tersebut dengan menambah akhiran 'an' untuk gaya 'Portugis' yang sebenarnya di Eropa dikenal sebagai gaya 'Spanish' dan 'Perancis' (di Eropa dikenal sebagai gaya 'French'). Istilah gaya 'Kompenian' sebenarnya merupakan pengembangan dari gaya 'Quenn Anne'. Gaya Rafllesan merupakan gaya mebel yang dipakai oleh Raffles ketika berkuasa di Jawa, berupa paduan gaya Sheraton dan ragam Mesir purba.

\subsubsection{Gaya Portugisan}

Gaya Portugisan berkembang pada beberapa jenis mebel yang awalnya dibawa bangsa Portugis ke tanah Jawa. Hal itu mengingat bahwa bangsa Portugis pernah secara langsung berhubungan dagang dengan masyarakat Jawa sekitar tahun 1510. Membandingkan ciri-ciri visual gaya Portugisan dengan gaya pada 'kebudayaan Portugis' di negeri asalnya ditemui banyak kesamaan, terutama dari periode Mudejar (sekitar tahun 1250-1500), dan periode Plateresque (tahun 1500-1550). Berdasar rautan sejarah kebudayaan dunia, masa tersebut dikenal sebagai jaman Renaisan awal.

Masa tersebut di Portugis sendiri dikenal sebagai perioda 'kebudayaan Spanyol'. Menurut Joseph Aronson kebudayaan Portugis hakiktanya mengikuti atau menyesuaikan diri pada 'kebudayaan Spanyol', sehingga untuk memudahkan pengklasifikasian historis pada masa itu periode kebudayaan Portugis tersebut oleh para ahli sejarah dikenal sebagai periode 'kebudayaan Spanyol'. (Joseph Aronson : 1970 : 343)

Adanya pengaruh kebudayaan Portugis atau Spanyol itu dalam membentuk tradisi mebel di Jawa disebabkan mebel masih merupakan sesuatu yang baru bagi masyarakat Jawa. Pada waktu itu belum berkembang pengetahuan teknik membuat mebel yang baik. Kemudian para pembuat mebel di Jawa meniru dan 
mengikuti saja gaya mebel yang dibawa oleh bangsa Portugis tersebut dan dipadukan dengan nilai estetis setempat.

Gaya 'Portugisan' dibedakan menjadi dua kelompok, pertama, dalam bahasa Jawa disebut "jeglogan", yang berarti penyisipan suatu bahan ke dalam bidang kayu yang telah dicungkil, yang kerap disebut dengan istilah "inlay". Teknik jeglogan merupakan inspirasi yang berasal dari bangsa Moor, kemudian menjadi salah satu ciri utama periode Mudejar.

Sejak kedatangan bangsa Portugis di Jawa, teknik jeglogan memperkaya perbendaharaan ragam pembuatan mebel di tanah Jawa. Kebanyakan digunakan untuk pengisi atau penghias bidang, khususnya pada perabotan. Bahan sisipan yang biasa digunakan adalah tulang, gading, kerang, kulit penyu, dan kuningan. Penerapan ragam hiasnya berbentuk geometris, atau lebih sering lagi mencerminkan bentuk-bentuk arsitektur, seperti lengkungan kubah atau gerbang (seperti bentuk dalam arsitektur Islam), dan.teknik penyelesaian yang biasa digunakan adalah "beningan" (semacam vernis).

Kelompok kedua, adalah gaya yang benar-benar disebut sebagai gaya Portugisan. Ciri gaya ini secara keseluruhan mempunyai penampilan "pekerjaan kayu kasar", seolah tidak ditangani oleh ahli ukir. Bentuk sangat sederhana dan kaku, seolah tidak banyak berubah dari bentuk dasar bahannya, yaitu balok dan papan. Ukuran ditentukan atas dasar kekuatan tanpa mempertimbangkan proporsi, sehingga berkesan bersahaja, masif dan berat.

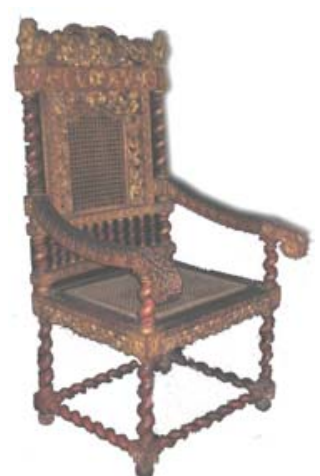

(a)

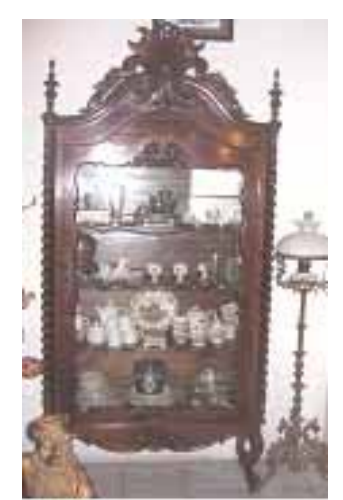

(b)

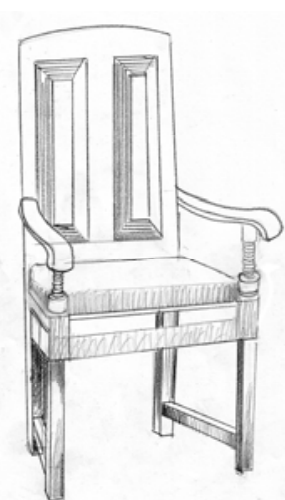

(c)

Gambar 14 (a,b) Gaya 'Portugisan' pada kursi dan lemari; (c) Gaya 'Portugisan' yang menampilkan kayu kasar.

Ragam hias yang banyak diterapkan berbentuk bubutan dan ulir (spiral), terutama untuk tiang tempat tidur dan lemari, kaki meja dan kursi. Ukiran 
bermotif geometris dibentuk dengan teknik cukil, sehingga membentuk relief dangkal dan lebih bersifat datar. Penggunaan ukiran terbatas untuk mengisi bidang kosong atau untuk menampilkan bagian yang dianggap penting atau perlu ditampilkan. Mebel Portugisan terdiri dari berbagai macam perlengkapan, beberapa di antaranya adalah: tempat tidur, lemari, meja, dan kursi.

Bahan baku yang bisaa digunakan adalah kayu jati. Untuk dudukan kursi digunakan anyaman rotan atau kain sutera. Bahan perlengkapan untuk keperluan konstruksi digunakan besi tempa, sedangkan untuk elemen estetis digunakan pula pelat kuningan (dibentuk dan diberi motif dengan cara diketok).

\subsubsection{Gaya 'Kompenian'}

Disebut: gaya Kompenian karena diperkirakan berkembang pada masa kekuasaan Kompeni di Jawa (sekitar abad ke 17). Perkiraan tahun secara lebih tepat menurut John Gloag adalah pada sekitar tahun 1650, yaitu berdasarkan tahun dimulainya ekspor mebel "kursi bakul” (dianggap mempunyai ciri serupa dengan gaya Kompeni).

Hadirnya gaya Kompenian mencerminkan adanya akulturasi antara ragam Eropa dan Cina. Pengaruh Eropa terlihat dari bentuk kaki sedangkan pengaruh ragam Cina terlihat pada bentuk-bentuk lengkung pembatas bidang, terutama pada bidang; sandaran kursi. Hal yang melatarbelakangi terjadinya bentuk campuran ini diketahui bahwa di beberapa negara Eropa (sekitar akhir abad 18) berkembang suatu perhatian atau kesenangan terhadap seni Timur. Ragam hias yang paling disenangi adalah yang berasal dari kebudayaan atau kesenian Cina. Perkembangan gaya "campuran" ini mencapai puncaknya di Inggris pada masa pemerintahan Queen Anne, tahun 1702-1714. Selanjutnya gaya ini disebut gaya Queen Anne, dan menjadi salah satu unsur penting dalam pembentukan gaya Baroque di Eropa. (Joseph Aronson : 192-316).

Masuknya gaya ini dimungkinkan oleh adanya usaha ekspor mebel ke Eropa oleh para usahawan VOC berusaha memanfaatkan bahan, keahlian dan kebudayaan bagi kepentingan perdagangan mebelnya di Eropa. Selanjutnya gaya tersebut menandai perkembangan mebel di Jawa pada masa kekuasaan VOC. Dibandingkan dengan gaya Queen Anne yang berkembang di Eropa, mebel gaya Kompenian mempunyai ciri visual yang mirip. Perbedaannya terletak pada bentuk dan jenis hiasan, serta teknik penyelesaiannya.

Motif ukiran mebel gaya Kompenian bisanya berbentuk tumbuhan, yaitu sulur, daun, dan bunga, serta bentuk binatang, terutama burung dan naga. Ukiran digunakan sebagai "isen-isen" (unsur pengisi bidang), dibuat menjadi relief 
yang dangkal sehingga memberi kesan datar (dua dimensi). Motif ukiran disusun bagai sebuah bentuk daun.
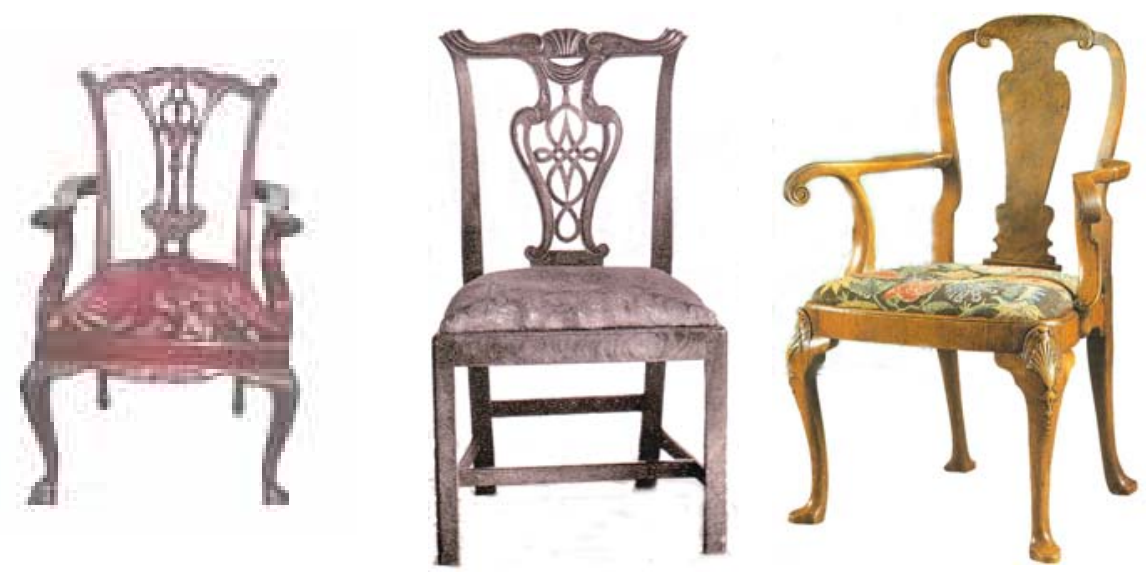

Gambar 15 Berbagai macam kursi bergaya 'Kompenian'.

Pengaruh kebudayaan Cina terlihat melalui bentuk-bentuk lengkung yang banyak ditemui pada bidang sandaran kursi dibuat mengikuti bentuk "out-line" bejana bunga (vase) Cina, dan gambaran berbentuk batu karang, mengingatkan bentuk yang banyak ditemui pada lukisan Cina. Hiasan gambar pemandangan atau rumah Cina seperti yang banyak dijumpai pada mebel Queen Anne, pada mebel gaya Kompenian sama sekali tidak dikenal.

Lahan baku mebel gaya Kompeni adalah kayu jati. Bahan tambahan aterdiri dari anyaman rotan untuk dudukan dan sandaran kursi, kaca bening untuk bidang isian dinding dna pintu lemari buku. Perlengkapan tambahan dibuat dari besi tempa. Teknik penyelesaian mebel gaya Kompeni bisaanya menggunakan bahan lak "jabung semut" atau "jabung kemalo". Berwarna merah atau hitam. Ukiran dan bidang pinggulan ditutup dengan "prada: (emas bubuk), menjadi unsur hias utama. (Gloag : 1977 : 417). Satu-satunya ciri yang sama dengan mebel Queen Anne adalah bentuk kaki "ngebuh" atau bengkok. Dalam bahasa Inggris kaki jenis ini disebut "cabriole". Menurut bentuknya, kaki bengkok dibedakan dan disebut "cakar garuda" "kaki macan" "bundelan” dan "buledan” atau polos.

Jenis mebel bergaya Kompenian terdiri dari berbagai macam perlengkapan, mulai dari tempat tidur hingga penyangga lilin. Diantara perlengkapan tersebut, jenis yang perlu dibahas adalah lemari dan kursi. Lemari bergaya Kompenian dibuat dalam berbagai ukuran. Lemari yang mempunyai ukuran tergolong besar atau lebih tinggi dari tubuh manusia, biasanya dibuat dengan konstruksi 
“lepasan” (lepas-pasang). Dalam keadaan dilepas, bagian-bagiannya terdiri dari: "Cunduk" atau mahkota, "pyan" atau atap, "inep" (daun pintu), "sampingan” dinding samping, "geger” (dinding belakang), "andapan” atau lemari bagian bawah (biasanya berbentuk seperti meja rendah dan berlaci). Ditinjau menurut penggunaan, kursi-kursi bergaya Kompenian dinilai kurang nyaman untuk diduduki. Ukuran dan proporsi kurang sesuai dengan ukuran tubuh manusia, seolah lebih mementingkan penampilan bentuk atau rupa daripada kenyamanan dalam penggunaan.

\subsubsection{Gaya 'Perancisan'}

Gaya Perancisan dilihat dari segi visual, terdapat kesesuaian dengan gaya mebel di Perancis pada jaman Louis XIV. Di Perancis ciri ini dikukuhkan sebagai suatu gaya yang disebut "Regence". (Joseph Avonso: 1970 : 343). Mengingat Perancis pernah berkuasa di Jawa dan Daendels sebagai seorang Gubernur Jenderal yang mewakili pemerintahan Napoleon di Jawa, menerapkan tata cara baru dalam upacara "Pasowanan", yaitu mengharuskan pihak keraton menyediakan perlengkapan permebelan bagi Residen atau para pembesar Belanda yang bertamu. Bukti yang mendukung kemungkinan tersebut adalah adanya jenis Mebel yang menurut sebutan di Jawa dinamakan lemari komodo dan kursi "medallion”.
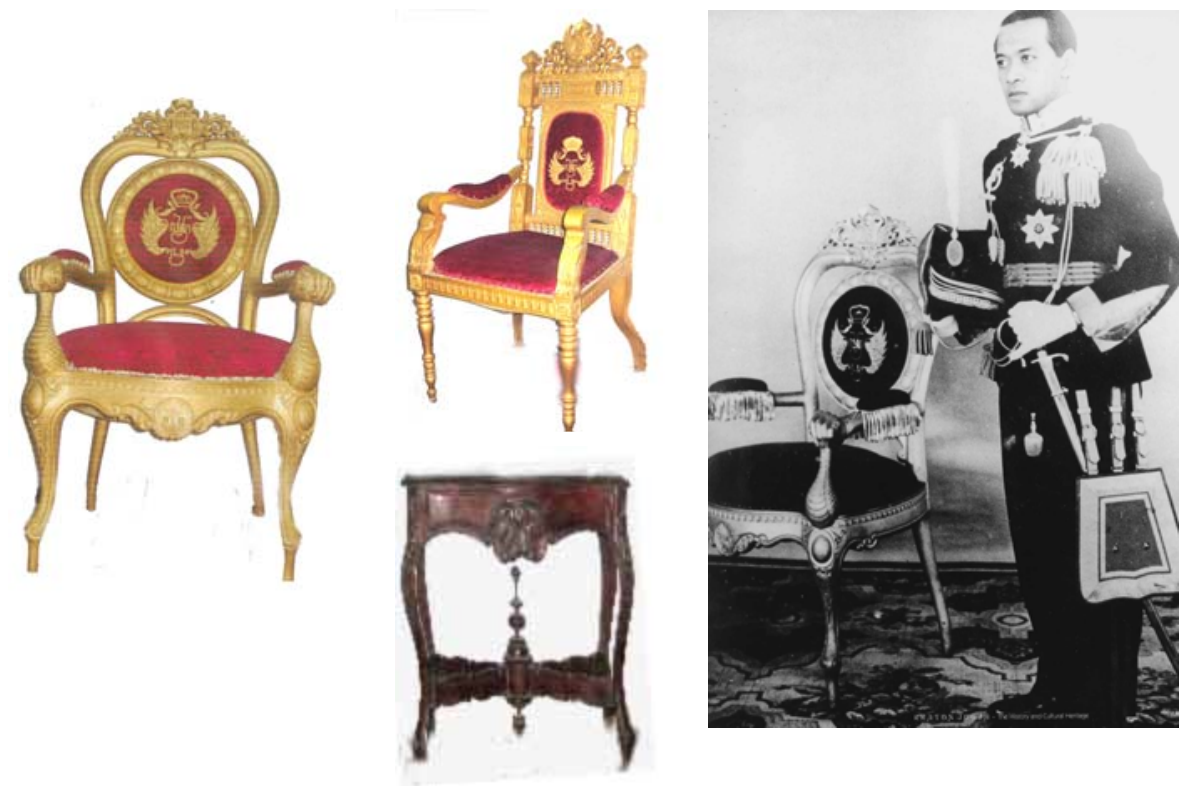

Gambar 16 Kursi dan meja bergaya Perancisan di keraton Yogyakarta, Sri Sultan Hamengku Buwono IX berdiri di samping kursi bergaya Perancisan. 
Pengaruh gaya Regence di Jawa di perkirakan masuk wilayah Nusantara sekitar tahun 1700-1811.Perkiraan ini didasarkan atas pertimbangan bahwa sejak tahun 1700, Belanda menjadi salah satu propinsi Perancis, dan pada tahun 1811 kekuasaan Perancis di Jawa direbut Inggris. Pada dasarnya gaya Perancisan merubah bentuk kaku dan lurus menjadi bentuk yang lembut dan luwes. Bentuk persegi dan sudut siku di rubah menjadi lengkungan, struktur-strukturnya dibuat alur lengkung yang menerus. Pada bagian sambungan tegak lurus alur dibentuk meliuk untuk menghilangkan atau mengaburkan sambungannya.

Prinsip dasar gaya Perancisan adalah merubah bentuk kaku dan garis lurus, menjadi bentuk yang lembut atau luwes. Bentuk persegi dan sudut siku dirubah menjadi lengkungan. Bagian yang merupakan struktur raebel, misalnya kaki, palang kaki, penahan sandaran, dudukkan dan tanganan, dibuat alur lengkung yang menerus. Pada bagian yang bersambungan tegak lurus, alur dibentuk meliuk dengan maksud untuk menghilangkan atau mengaburkan bentukbentuk sambungannya. Bentuk kaki mebel gaya 'Perancisan' mempunyai kesamaan dengan bentuk kaki raebel Regence, yaitu yang disebut "pied-debiche" (bhs. Perancis), yang berarti kaki kijang. Dinamakan kaki kijang karena mempunyai telapak kecil dan runcing.

Motif ukiran meniru bentuk-bentuk antara lain, yaitu: kerang, daun, bunga dan sulur. Bahan baku yang banyak digunakan adalah kayu yang termasuk golongan "kayu alus", seperti sono keling, sutra Ambon, mahoni, dan sebagainya. Teknik finsishing biasanya menggunakan sistem "beningan", mengikuti teknik yang banyak digunakan di Perancis sejak tahun 1740, yaitu "vernis".

Jenis mebel yang dianggap mewakili gaya Perancisan adalah lemari komodo, yang dikenal juga dengan sebutan "prongkas". Kata "prongkas" berasal dan istilah "pronk kast" (bhs. Belanda), diartikan sebagai lemari yang digunakan untuk memajang barang pecah belah. Biasanya berdaun pintu tunggal. Dinding samping maupun daun pintu dibuat dari kaca bening. Atap berbentuk kubah dan dihias dengan "cunduk" (mahkota) berukir. Kedua sisi pintu terdapat tiang setinggi permukaan atap, pada puncaknya dihias dengan berbentuk ukiran kayu.

\subsubsection{Gaya 'Majapahitan'}

Bersamaan dengan itu, di tahun 1804 merupakan awal perkembangan dunia industri mebel di Jepara, dan di abad ke-19 itu merupakan abad penting dalam pertumbuhan industri seni dan kerajinan di wilayah Nusantara pada masa kolonial. Kegiatan industri seni dan kerajinan merupakan bagian kegiatan nonpertanian yang pada dekade awal abad itu kembali menunjukkan peranannya dalam perekonomian masyarakat Jawa. Kondisi tersebut juga mempengaruhi 
gaya mebel yang berada di keraton Yogyakarta meskipun tidak terlampau dominan.
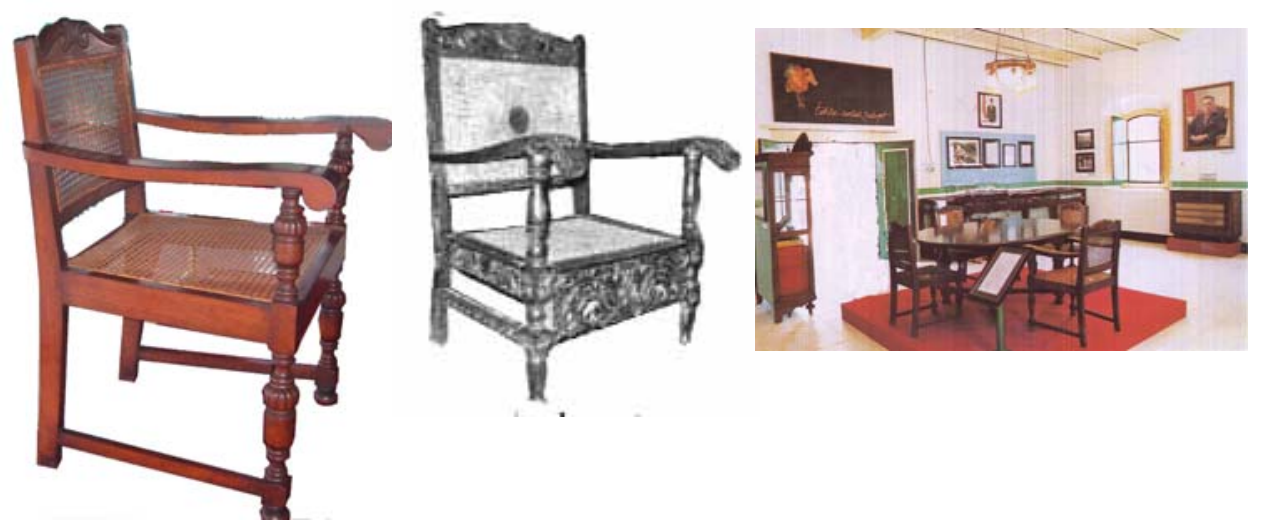

Gambar 17 Kursi bergaya Majapahitan di Keraton Yogyakarta.

Di abad ke-20 mebel ukir berhasil memasuki rumah-rumah hunian kalangan atas masyarakat kolonial. Produk mebel dihasilkan pada waktu itu antara lain berupa kursi dan bangku teras berukuran panjang yang dikombinasikan dengan rotan dan menyerupai kursi buatan industri mebel Moris dan Co yang dibuat pada tahun 1893 di Eropa. Hal itu dapat dilihat pada alas duduk dan sandaran kursi dan juga meja tamu.

Di antara kursi-kursi yang di produksi tersebut di atas yang paling populer adalah kursi yang kemudian disebut sebagai kursi gaya 'Majapahitan' yaitu kursi dengan ukiran dengan ragam hias corak Majapahit berupa paduan ragam hias Hindu, Mataram dan Yogya di tambah dengan penggunaan rotan untuk sandaran punggung dan alas sarana duduk.

\section{$7 \quad$ Simpulan}

Karakteristik estetik mebel yang berada di Keraton Ngayogyakarta Hadiningrat memiliki beragam peran, baik peran fungsional, maupun peran sosial. Demikian pula beragamnya ragam hias pada mebel di keraton Yogyakarta dipengaruhi oleh budaya Jawa-Hindu dan juga budaya asing merupakan bukti bahwa budaya keraton memiliki keterbukaan. Selain itu, ragam hias pada mebel di keraton ditentukan oleh kemampuan pengrajin dalam mengolah dan mengembangkan ragam hias, disamping tidak tertutup pesanan fihak keraton sendiri. Hal ini menunjukkan masyarakat keraton yang egaliter dan dapat menerima pemikiran masyarakat di luar keraton. 
Kandungan makna dalam ragam hias mebel keraton hakikatnya dibangun sejalan dengan fungsi dan peristiwa. Sebagai simbol kekuasaan tertinggi terutama perabotan yang dipergunakan oleh raja dan permaisuri, mebel keraton memiliki kualitas lebih tinggi dibandingkan dengan mebel masyarakat biasa. Beberapa mebel, khususnya kursi disamping menerapkan pelbagai gaya visual secara multi kultural, juga menerapkan simbol-simbol keagungan kerajaan, sehingga memiliki kedayaan yang tinggi menghadapi arus perubahan yang terjadi di luar keraton.

\section{Daftar Pustaka}

[1] Purwadi. 2006. Sejarah Kanjeng Sultan Hamengku Buwono IX, Hanan Pustaka Yogyakarta.

[2] Christopher Payne. 2001. Collecting Furniture, London E 14 4JP.

[3] Djumhur.1977. Antropologi Budaya, Dirgantara, Bandung.

[4] Haryanto, Eko. 2004. Ragam Hias Kursi Kayu Tunggal Jawa Tengah Abad ke 17-20, Tesis, Fakultas Senirupa dan Desain ITB.

[5] Gustami. 2000. Seni Kerajinan Mebel Ukir Jepara, Kajian Estetik Melalui Pendekatan Multidisiplin, Yogyakarta, hal.185.

[6] Koentjaraningrat. 1994. Kebudayaan Jawa, Jakarta, Balai Pustaka.

[7] Gloag, John. 1973. English Furniture, Adam \& Charles Black, London.

[8] Gottshall, Franklin. 1989. Period Furniture, Bonanza Books, New York.

[9] Toekio, Soegeng M. 1987. Mengenal Ragam Hias Indonesia, Bandung, Angkasa.

[10] Hoop, Van Der. 1949. Ragam-ragam Perhiasan Indonesia, Jakarta, Koninklijk Bataviaasch Genootshap Van Kunsten En Wetenschappen.

[11] Sachari, Agus. 1990. Nilai Estetik Pada Desain Furnitur Tradisional Masyarakat Jawa, LPPM.

[12] Speltz, Alexander. 1996. Style of Ornament, London: Bracken B.

[13] Soemardjan, Selo. 1981 Perubahan Sosial di Yogyakarta, Gajahmada University Press, Yogyakarta.

[14] Sunarko, Ken. 1981. Mebel Kuno Jawa, Skripsi FSRD ITB, hal.17. 